\title{
EVALUATION OF MLR AND GWR REGRESSION MODELS OF CURRENT ANNUAL INCREMENT PREDICTED BY GROWING STOCK, TOPOGRAPHICAL AND LANDSAT 8 SPECTRAL DATA IN THE NORTHEAST BOSNIAN MIXED FOREST
}

\author{
Evaluacija MLR i GWR regresionih modela zavisnosti tekućeg zapreminskog prirasta \\ drvne produkcije od zalihe drvne mase, topografskih i spektralnih Landsat 8 podataka u \\ mješovitim šumama sjeveroistočne Bosne
}

\author{
Azra Čabaravdić ${ }^{1}$, Ibrahimspahić Aida ${ }^{1}$, Merisa Osmanović ${ }^{2}$, Starčević Mirsada ${ }^{2}$

\section{Abstract}

The aim of this research was to evaluate estimates of the current annual increment of volume (CAIv) variability considering growing stock (V) as structural variable and topographic conditions and Landsat 8 spectral response as environmental variables on hilly and mountainous mixed forests in the northeast Bosnia using multiple linear regressions based on ordinary least squares (MLR) and geographically weighted regression (GWR).

Sample data contains geo-referenced forest inventory data, CAIv $\left(\mathrm{m}^{3} /\right.$ ha/year) and V $\left(\mathrm{m}^{3} / \mathrm{ha}\right)$, extracted values from digital terrain model (altitude, slope and aspect) and derived principal components values from Landsat 8 satellite image for forest stands of the management unit located on hilly and mountain positions in protected area Konjuh, Kladanj. Here are applied MLR and GWR using stepwise procedure. MLR and GWR analyses resulted with global coefficients of significant predictors on hilly position. This was expected due to homogenous vegetation and environmental conditions on hilly position. It was found that growing stock affected CAIv the most. Significant improvement of regression modeling is achieved by GWR appliance on sample from mountainous position. There were obtained local influence of growing stock and the first principle component related to green biomass on CAIv. The highest improvement is found for broadleaves CAIv where quantification of local variability of growing stock increased adjusted coefficient of determination about $11 \%$ and reduced relative root mean square error for $6 \%$. Local character of green biomass related to conifers CAIv did not improve regression estimation significantly. The broadleaves root mean square error based on GWR was $1.60 \mathrm{~m}^{3} / \mathrm{ha} /$ year (coefficient of variation more than $30 \%$ ) which is still high so further modeling including other structural characteristics (stems number, basal area, mixture) as predictors is required.

Key words: current annual increment, structural and environmental predictors, Landsat 8, ordinary and geographically weighted regression

\footnotetext{
${ }^{1}$ University of Sarajevo, Faculty of Forestry

${ }^{2}$ University of Sarajevo, Institute of forestry and urban greenery
} 


\section{INTRODUCTION - Uvod}

Classical sustainable forest management is focused on continuous the highest wood production conducting measures to improve structural characteristics of forest stands in interaction with environmental influences. Structural characteristics of forest stand consider forest production attributes as growing stock, current annual increment of volume (CAIv), basal area, trees number and other attributes per area unit managed by planned silvicultural treats. Forest management planning in Bosnia and Herzegovina as the basic planning unit use forest management class consisted of several stands with distinguish forest types on similar soils whit unique planned management goal.

Usually forest management class contains several forest stands distributed on wide area so spatial environmental variability affects structural characteristics inside the same management class. From planning point of view, it is important to differentiate relative importance of planned treatments and environmental influences on forest production. The current annual increment of wood volume per ha is assigned as the most important attribute produced on managed growing stock with influence of environmental variables.

Considering the growing stock as result of planned treatments and environmental impact which is not under human control, it arises question about its relative importance on the current annual increment inside unique management class on variable terrain positions.

The goal of this paper is to evaluate the current annual increment estimates based on the growing stock as structural component influenced by planning and environmental variables captured spatially on two parts of one management class - on the hilly and mountainous positions using MLR and GWR methods. Environmental variables refer to topographic (altitude, slope, aspect) and Landsat 8 spectral derived features. The following aims were stated: (1) to determine multiple linear regression models for CAIv depending of structural and environmental variables using ordinary least square (MLR) and geographically weighted regression (GWR) on hilly and mountainous positions, (2) evaluate significant predictors characters (global or local) and (3) suggest management measures according to character of significant predictors.

\section{MATERIAL AND METHODS OF RESEARCH - Materijal i metode istraživanja}

Study area, also as a part of the Forest Management area "Sprečko" is located in the north-east part of Bosnia situated between longitudes $18^{\circ} 29-18^{\circ} 37^{\prime}$ and latitudes $44^{\circ} 23-44^{\circ} 17^{\prime}$. The research is conducted for beech and fir mixed forest located on hilly and mountainous positions of the locality Oskova in the north-east part of Bosnia (Figure 1 a.). The terrain measurement data were collected during regular forest inventory in 2012 according to current methodology for state-owned forest inventory in Bosnia and Herzegovina. For the purpose of this research it was selected a sample consisted of sample plots distributed in the unique classification unit (management class) named as beech and fir mixed forest on deep soils (dystric, eutric 
Evaluation of MLR and GWR regression models of current annual increment predicted by growing stock, topographical and Landsat 8 spectral data in the northeast Bosnian mixed forest

and humic cambisols, dystric regosols, lithic leptosols) (Figure 1 b.). Visual analysis of terrain shoved that one part of sample plots was distributed on almost plane lower altitudes assigned as hilly and other part was scattered on steep mountainous higher altitudes. In order to homogenize predictors sample was divided on two sub-samples related to hilly and mountainous position.

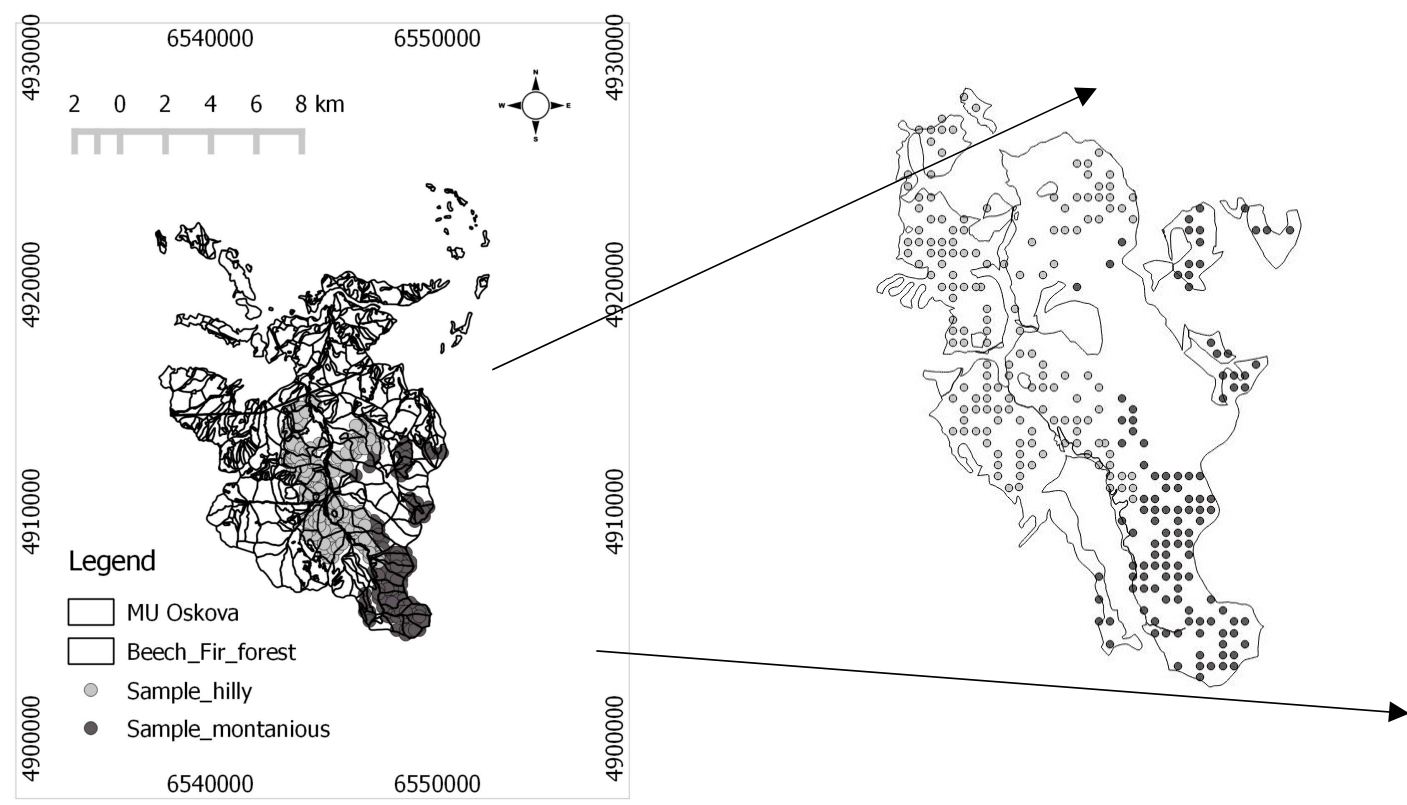

a.

b.

Figure 1. Management unit "Oskova”, FMU “Sprečko" (a.), Sampling plan in management class: beech and fir mixed forest on deep soils (b.)

Slika 1. Gospodarska jedinica “Oskova”, ŠGP "Sprečko” (a.), Plan uzorkovanja u gazdinskoj klasi: mješovite šume bukve i jele na dubokim tlima (b.)

Research material was composed from local assessments of growing stocks and volume increment for dominate tree species (beech and fir), groups (conifers and deciduous) and total growing stock on sample plots with known geo-position ( $\mathrm{x}$ and $\mathrm{y}$ coordinates). Growing stocks, as "carriers" of volume increment, were marked as structural predictor. There were analyzed different topographic effects on the volume increment as: altitude, slope and aspect, all obtained from digital terrain model. Slope data were transformed using equation: Slope ${ }^{\prime}=(2 / \pi) *(\operatorname{asin}(\operatorname{sqrt}($ slope in degree/100)) $)$. Aspect data were transformed using equation: $\operatorname{Aspect}^{\prime}=(\cos (\operatorname{radians}(0$-aspect $))+1) / 2$. Spectral source of CAIv variation was analyzed using Landsat 8 satellite image. The Landsat 8 image was recorded 21 July 2015 (path 188/row 29), preprocessed and the 
transformation of original digital values in to the reflection values was completed using QGIS software. It was used reflectance of six spectral bands (blue, red, green, NIR and two short wave infra-red (SWIR1 and SWIR2). The principal component analysis was performed on spectral bands and two statistically significant main principal components preserving about $94 \%$ variability were identified: the first component associated with green biomass (PCA 1), and the second associated with soil moisture (PCA 2).

Two parametric multiple linear regression analyses were implemented: ordinary least square method (MLR) and multiple geographically weighted regressions (GWR). Growing stock, topographic variables (altitude, slope, aspect) and two principal components were featured as predictors. The target variables were current annual increment of dominant species (beech and fir), groups (conifers and deciduous) and total volume increment.

Regression models using least square method were obtained with following equation:

$$
\hat{Y}_{i}=\hat{\beta}_{0}+\hat{\beta}_{1} X_{1}+\ldots+\hat{\beta}_{n} X_{n}+\varepsilon_{i}
$$

where $\hat{Y}_{i}$ is the observed CAIv, $X_{1} \ldots X_{n}$ are the independent variables or predictors (in this case structural, topographic and spectral variables), $\hat{\beta}_{0}$ constant, $\hat{\beta}_{1} \ldots \hat{\beta}_{n}$ are regression coefficients and $\varepsilon_{\mathrm{i}}$ are the random residuals. Regression models are determined using "step by step" regression procedure for normalized standardized predictors. There are determined statistically significant predictors used also in GWR determination. Geographically weighted regression considers geographically varying parameters. Standard (Gaussian) GWR model is described with equation:

$$
\hat{Y}_{i}=\sum_{k} \beta_{k}\left(u_{i}, v_{i}\right) x_{k, i}+\varepsilon_{i}
$$

where $\hat{Y}_{i}, x_{k, i}$, and $\varepsilon_{i}$ are, respectively, dependent variable, kth predictor and the Gaussian error at position $i,\left(u_{i}, v_{i}\right)$ is the $x$ and $y$ coordinate of the $\mathrm{k}^{\text {th }}$ position and coefficients $\beta_{i}\left(u_{i}, v_{i}\right)$ are variable occasions at the location (NAKAYA, 2014).

For Gaussian GWR model determination, aside from dependent variable and predictors, it was necessary to specify: (1) (x,y) coordinates (center of sample plot), (2) the character of independent variable (global, local), (3) the type of kernal function for geographically weighting in order to estimate local coefficients, (4) method for span size selection and (5) the selection model criteria for comparison with other modeling results using the same data. In this case were used terrain geo-location of sample plot centers $(\mathrm{x}, \mathrm{y})$, local character of independent variables, fixed Gaussian distance, search of golden section for optimal span size and AICc comparison criteria. The statistical significance improvement of using geographically regression model was evaluated by GWR analysis of variance. Detailed procedure and method description is given by CHARLTON ET AL. (2006), Austin (2007) and NAKAYA (2014). The results evaluation, apart from GWR analyses of variance, was completed 
Evaluation of MLR and GWR regression models of current annual increment predicted by growing stock, topographical and Landsat 8 spectral data in the northeast Bosnian mixed forest

comparing the values of adjusted determination and through graphical representation of comparative regression models. The multiple linear regressions were performed by Statgraphics Plus 5.0 software program. For GWR regression analyzes was used Windows application for GWR modeling (NAKAYA, 2014). Modeling processes were carried out for two sub-samples individually i.e. hilly and mountainous area.

Evaluations of MLR and GWR estimates were performed comparing the goodness-offit statistics (AIC), adjusted coefficient of determination, bias and relative root means square error values obtained for dominant species, broadleaf's, conifer's and altogether (total) CAIv's. Then observed CAIv values are correlated with MLR and GWR estimates taking into account the magnitude of spatial autocorrelation. Correlations were calculated using Clifford estimators integrating in SAM v.4 software (RANGEL ET AL., 2010). Here are compared spatial correlograms of observed, MLR and GWR estimated CAIv values for target variables where significant improvement is obtained.

\section{RESULTS - Rezultati istraživanja}

Presented results summaries descriptive statistics of CAIv as target variable and regression analysis performances with structural and environmental predictors on two distinctive forest areas: lower altitude with hilly terrain characteristics and higher mountainous heterogeneous area. Descriptive statistics (sample size, mean and 95\% confidence interval) for CAIv $\left(\mathrm{m}^{3} / \mathrm{ha} /\right.$ year) for all species (total), per groups (conifers and broadleaves) and per dominated tree species (fir and beech) for both hilly and mountainous position are presented in Table 1. The slightly higher total and broadleaves quantities of CAIv were obtained at mountainous position while conifers achieved higher mean CAIv on hilly position.

Table 1. Descriptive statistics for CAIv $\left(\mathrm{m}^{3} / \mathrm{ha} / \mathrm{year}\right)$

Tabela 1. Deskriptivna statistika za tekući zapreminski prirast ( $\left.I_{t}^{v} ; \mathrm{m}^{3} / \mathrm{ha} / \mathrm{god}\right)$

\begin{tabular}{|l|c|c|c|c|}
\hline \multirow{2}{*}{$\begin{array}{c}\text { CAIv } \\
\left(\mathrm{m}^{3} / \text { ha/year }\right)\end{array}$} & \multicolumn{2}{c|}{$\begin{array}{c}\text { Hilly } \\
(\mathrm{N}=153)\end{array}$} & \multicolumn{2}{c|}{$\begin{array}{c}\text { Mountainous } \\
(\mathrm{N}=117)\end{array}$} \\
\cline { 2 - 5 } & Mean & $\pm \mathrm{CI}$ & Mean & $\pm \mathrm{CI}$ \\
\hline Total & 7.91 & 0.55 & 8.52 & 0.59 \\
\hline Conifers & 3.47 & 0.41 & 3.30 & 0.47 \\
\hline Broadleaves & 4.44 & 0.43 & 5.21 & 0.53 \\
\hline Fir & 3.40 & 0.40 & 3.22 & 0.48 \\
\hline Beech & 4.08 & 0.41 & 5.06 & 0.53 \\
\hline
\end{tabular}

In order to perform regression analyses some target variables and predictors were normalized using Box-Cox transformation (in tables marked by *). Table 2 . displays coefficients of MLR regression models for the CAIv on hilly positions. The highest effect on CAIv had growing stock for all dependent variables $(>0.12)$ while topographic effects were very low $(<-0.003)$. Then, altitude and PCA 1 showed 
significant influence on CAIv for all analyzed categories (dominant species, groups and altogether). The highest adjusted coefficients of determination values were determined for fir and conifers $\left(R_{a d j}^{2}=76 \%\right)$. CAIv variability for broadleaves and beech explained by MLR models were slightly lower with $71 \%$.

Table 2. Coefficients of MLR regression models for CAIv $\left(\mathrm{m}^{3} / \mathrm{ha} / \mathrm{year}\right)$ on hilly positions

Tabela 2. Koeficijenti višestruke linearne regresije $I_{t}^{v}\left(\mathrm{~m}^{3} / \mathrm{ha} / \mathrm{god}\right)$ na brdskim područjima

\begin{tabular}{|c|c|c|c|c|c|c|}
\hline \multirow{2}{*}{\multicolumn{2}{|c|}{ Predictors }} & \multicolumn{5}{|c|}{ Current Annual Increment $\left(\mathrm{m}^{3} / \mathrm{ha} /\right.$ year) } \\
\hline & & \multirow{2}{*}{$\begin{array}{l}\text { Total } \\
-1.94 \\
\end{array}$} & \multirow{2}{*}{$\begin{array}{c}\text { Conifers * } \\
0.58 \\
\end{array}$} & \multirow{2}{*}{$\begin{array}{c}\text { Broadl.* } \\
0.65 \\
\end{array}$} & \multirow{2}{*}{$\frac{\text { Fir* }}{0.55}$} & \multirow{2}{*}{$\begin{array}{c}\text { Beech* } \\
0.62 \\
\end{array}$} \\
\hline & Intercept & & & & & \\
\hline \multirow{4}{*}{$\begin{array}{c}\text { Structural } \\
\text { (growing } \\
\text { stock } \\
\mathrm{m}^{3} / \mathrm{ha} \text { ) }\end{array}$} & Conifers * & 0.58 & 0.15 & & & \\
\hline & Broadl. * & 0.44 & -0.006 & 0.12 & -0.006 & \\
\hline & Fir * & & & 0.004 & 0.15 & 0.0007 \\
\hline & Beech * & & & & & 0.12 \\
\hline \multirow{3}{*}{ Topographic } & Altitude & -0.003 & -0.0006 & -0.0005 & -0.0005 & -0.0005 \\
\hline & Slope' & & & & -0.0003 & \\
\hline & Aspect' & & -0.0002 & & & \\
\hline \multirow{2}{*}{ Spectral } & PCA 1 & 0.55 & 0.04 & 0.10 & 0.04 & 0.09 \\
\hline & PCA 2 & 0.24 & 0.08 & & 0.07 & \\
\hline \multirow{2}{*}{$\begin{array}{c}\text { Model } \\
\text { evaluation }\end{array}$} & $R_{\text {adjoLS }}^{2}$ & $58 \%$ & $76 \%$ & $71 \%$ & $76 \%$ & $70 \%$ \\
\hline & $\mathrm{R}$ & 0.76 & 0.87 & 0.84 & 0.87 & 0.84 \\
\hline
\end{tabular}

* transformed data, Broadl. - Broadleaves

Then, geographically weighted regression was performed using significant predictors. Table 3. presents the GWR improvement on hilly position. No significant improvement of GWR in all analyzed categories were obtained $(\mathrm{p}>0.05)$. It was expected considering homogenous terrain conditions on lower altitude.

Table 3. Indicators of GWR improvement - hilly position

Tabela 3. Pokazatelji poboljšanja za GWR - brdsko područje

\begin{tabular}{|l|c|c|c|}
\hline $\begin{array}{c}\text { CAIv } \\
\left(\mathrm{m}^{3} / \text { ha/year }\right)\end{array}$ & $\mathrm{F}$ & $\mathrm{p}$ & AICc improvement \\
\hline Total & 1.72 & 0.11 & 5.93 \\
\hline Conifers & 1.57 & 0.14 & 6.50 \\
\hline Broadleaves & 1.65 & 0.09 & 6.87 \\
\hline Fir & 1.58 & 0.14 & 6.71 \\
\hline Beech & 1.64 & 0.09 & 7.06 \\
\hline
\end{tabular}


Evaluation of MLR and GWR regression models of current annual increment predicted by growing stock, topographical and Landsat 8 spectral data in the northeast Bosnian mixed forest

Further, coefficients of MLR regression models for CAIv $\left(\mathrm{m}^{3} /\right.$ ha/year) on mountainous positions are presented in Table 4. The deficiency of topographic predictors values indicate their statistical insignificance on CAIv for mountainous positions although we expected their significant influence. The highest determination values were registered for fir $\left(R_{a d j}^{2}=77 \%\right)$ and conifers $\left(R_{a d j}^{2}=76 \%\right)$ based on growing stock while environmental participation was very low.

Table 4. Coefficients of MLR regression models for CAIv ( $\mathrm{m}^{3} / \mathrm{ha} /$ year) on mountainous position

Tabela 4. Koeficijenti višestruke linearne regresije $I_{t}^{v}\left(\mathrm{~m}^{3} / \mathrm{ha} / \mathrm{god}\right)$ na planinskom području

\begin{tabular}{|c|c|c|c|c|c|c|}
\hline \multirow{2}{*}{\multicolumn{2}{|c|}{ Predictors }} & \multicolumn{5}{|c|}{ Current Annual Increment ( $\mathrm{m}^{3} /$ ha/year) } \\
\hline & & \multirow{2}{*}{$\frac{\text { Total }}{1.27}$} & \multirow{2}{*}{$\begin{array}{c}\text { Conifers * } \\
0.56\end{array}$} & \multirow{2}{*}{$\begin{array}{c}\text { Broadl. } \\
1.65\end{array}$} & \multirow{2}{*}{$\frac{\text { Fir * }}{0.58}$} & \multirow{2}{*}{$\frac{\text { Beech }}{1.49}$} \\
\hline & Intercept & & & & & \\
\hline \multirow{4}{*}{$\begin{array}{c}\text { Structural } \\
\text { (growing } \\
\text { stock } \\
\mathrm{m}^{3} / \mathrm{ha} \text { ) }\end{array}$} & Conifers * & 0.05 & 0.14 & & & \\
\hline & Broadl. & 0.01 & & 0.02 & & \\
\hline & Fir $*$ & & & & 0.14 & \\
\hline & Beech & & -0.001 & & -0.001 & 0.02 \\
\hline \multirow{2}{*}{ Spectral } & PCA 1 & 0.31 & 0.03 & & 0.03 & \\
\hline & PCA 2 & & & -0.34 & & -0.34 \\
\hline \multirow{2}{*}{$\begin{array}{c}\text { Model } \\
\text { evaluation }\end{array}$} & $R_{\text {adjOLS }}^{2}$ & $43 \%$ & $76 \%$ & $54 \%$ & $77 \%$ & $55 \%$ \\
\hline & $\mathrm{R}$ & 0.66 & 0.87 & 0.73 & 0.88 & 0.74 \\
\hline
\end{tabular}

* transformed data, Broadl. - Broadleaves

GWR model for CAIv ( $\mathrm{m}^{3} /$ ha/year) for mountainous positions is given in Table 5 . GWR provided varying coefficients for intercept, structural growing stock of conifers, broadleaves and beech and environmental PCA 1 (green biomass). The local effects of green biomass to total CAIv were greater than other predictors. The varying coefficients of other coefficients were low and almost same for all dependent variables indicating similar local variations. 
Table 5. Coefficients of GWR regression models for CAIv $\left(\mathrm{m}^{3} / \mathrm{ha} / \mathrm{year}\right)$ on mountainous position

Tabela 5. Koeficijenti geografski ponderisane regresije $I_{t}^{v}\left(\mathrm{~m}^{3} / \mathrm{ha} / \mathrm{god}\right)$ na planinskom području

\begin{tabular}{|c|c|c|c|c|c|c|}
\hline \multirow{2}{*}{\multicolumn{2}{|c|}{ Predictors }} & \multicolumn{5}{|c|}{ Current Annual Increment ( $\mathrm{m}^{3} /$ ha/year) } \\
\hline & & Total & Con. * & Broadl. & Fir * & Beech \\
\hline & Intercept & $2.23\left(\mathrm{x}_{\mathrm{i}}, \mathrm{y}_{\mathrm{i}}\right)$ & 0.57 & 1.39 & 0.58 & 1.32 \\
\hline \multirow{4}{*}{$\begin{array}{l}\text { Structural } \\
\text { (growing } \\
\text { stock } \\
\mathrm{m}^{3} / \mathrm{ha} \text { ) }\end{array}$} & Con.* & $0.02\left(\mathrm{x}_{\mathrm{i}}, \mathrm{y}_{\mathrm{i}}\right)$ & 0.14 & & & \\
\hline & Broadl. & 0.01 & & $0.02\left(\mathrm{x}_{\mathrm{i}}, \mathrm{y}_{\mathrm{i}}\right)$ & & \\
\hline & Fir $*$ & & & & 0.14 & \\
\hline & Beech & & -0.001 & & -0.001 & $0.02\left(\mathrm{x}_{\mathrm{i}}, \mathrm{y}_{\mathrm{i}}\right)$ \\
\hline \multirow{2}{*}{ Spectral } & PCA 1 & $0.17\left(\mathrm{x}_{\mathrm{i}}, \mathrm{y}_{\mathrm{i}}\right)$ & $0.02\left(\mathrm{x}_{\mathrm{i}}, \mathrm{y}_{\mathrm{i}}\right)$ & & $-0.02\left(\mathrm{x}_{\mathrm{i}}, \mathrm{y}_{\mathrm{i}}\right)$ & \\
\hline & PCA 2 & & & -0.25 & & -0.26 \\
\hline \multirow{2}{*}{ Models evaluation } & $R_{\text {adjGWR }}^{2}$ & $47 \%$ & $77 \%$ & $65 \%$ & $78 \%$ & $66 \%$ \\
\hline & $R$ & 0.69 & 0.88 & 0.81 & 0.88 & 0.81 \\
\hline \multicolumn{2}{|c|}{$R_{a d j O L S}^{2}-R_{a d j G W R}^{2}$} & $4 \%$ & $1 \%$ & $11 \%$ & $1 \%$ & $11 \%$ \\
\hline
\end{tabular}

* - transformed data, Con. - Conifers, Broadl. - Broadleaves

The highest local adjusted coefficient of determination values were registered for fir and conifers CAIv $\left(R_{a d j_{-} G W R}^{2} \approx 77.5 \%\right)$ slightly reducing global adjusted coefficient of determination (about 1\%). Although adjusted coefficient of determination values for group broadleaves and beech were lower (about 65.5\%), GWR model increased variability explanation with about $11 \%$. It means that broadleaves and beech growing stock variability over the study area should be analyzed locally.

Table 6 represents the GWR improvement achieved on mountainous position. Calculated $p$ values for fir and conifers exceeded critical value of 0.05 indicating nonsignificant change while for GWR estimates for CAIv of beech, broadleaves and altogether were significantly improved $(\mathrm{p}<0.05)$. According to results, AICc improvements were the highest for broadleaves and beech. 
Evaluation of MLR and GWR regression models of current annual increment predicted by growing stock, topographical and Landsat 8 spectral data in the northeast Bosnian mixed forest

Table 6. Indicators of GWR improvement - mountainous position

Tabela 6. Pokazatelji poboljšanja za GWR - planinsko područje

\begin{tabular}{|l|c|l|c|}
\hline $\begin{array}{c}\text { CAIv } \\
\left(\mathrm{m}^{3} / \text { ha/year }\right)\end{array}$ & $\mathrm{F}$ & \multicolumn{1}{c|}{$\mathrm{p}$} & AICc improvement \\
\hline Total & 2.46 & 0.02 & 0.47 \\
\hline Conifers & 2.46 & 0.200 & 3.50 \\
\hline Broadleaves & 1.73 & 0.001 & 13.68 \\
\hline Fir & 2.46 & 0.24 & 3.75 \\
\hline Beech & 1.73 & 0.0007 & 14.16 \\
\hline
\end{tabular}

The comparison of MLR and GWR for mountainous position based on the RMSE's is presented in Table 7. The higher relative RMSEs for MLR were registered for beech, broadleaves and altogether ranging from $25 \%$ to $40 \%$. Relative improvement in interval from $1 \%$ to $7 \%$ was obtained by GWR.

Table 7. Regression models evaluation - mountainous position Tabela 7. Evaluacija regresionih modela-planinsko područje

\begin{tabular}{|l|c|c|c|c|c|c|c|c|c|}
\hline \multirow{2}{*}{$\begin{array}{c}\text { CAIv } \\
\left(\mathrm{m}^{3} / \text { ha/year }\right)\end{array}$} & bias & $\begin{array}{c}\text { RMS } \\
\text { E }\end{array}$ & $\begin{array}{c}\text { \%RMS } \\
\text { E }\end{array}$ & bias & $\begin{array}{c}\text { RMS } \\
\text { E }\end{array}$ & $\begin{array}{c}\% \text { RMS } \\
\text { E }\end{array}$ & $\begin{array}{c}\text { bia } \\
\text { s }\end{array}$ & $\begin{array}{c}\text { RMS } \\
\text { E }\end{array}$ & $\begin{array}{c}\% \text { RMS } \\
\text { E }\end{array}$ \\
\hline Total & 0.0 & 2.38 & 27.90 & 0.09 & 2.25 & 26.41 & $\begin{array}{c}0.0 \\
9\end{array}$ & 0.13 & 1.49 \\
\hline Broadleaves & 0.0 & 1.93 & 36.99 & 0.00 & 1.62 & 31.16 & $\begin{array}{c}0.0 \\
0\end{array}$ & 0.30 & 5.83 \\
\hline Beech & 0.0 & 1.92 & 37.99 & 0.00 & 1.60 & 31.61 & 0 & 0.32 & 6.38 \\
\hline
\end{tabular}

In the Figure 2 is graphically presented the relation between observed and MLR and GWR predicted values for broadleaves. The both models overestimates CAIv in the low $\left(<4 \mathrm{~m}^{3} /\right.$ ha/year) and high range $\left(>8 \mathrm{~m}^{3} /\right.$ ha/year $)$, but it seems that GWR are half of MLR values. Also, it is visible that MLR residuals are scattered in wider interval $( \pm 3)$ while GWR residuals are closer to zero. The predictive performance of MLR model seemed to be more accurate. 


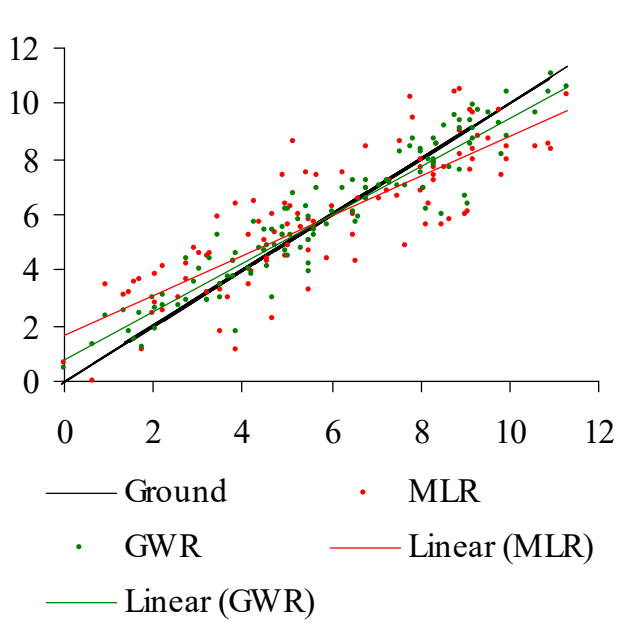

a.

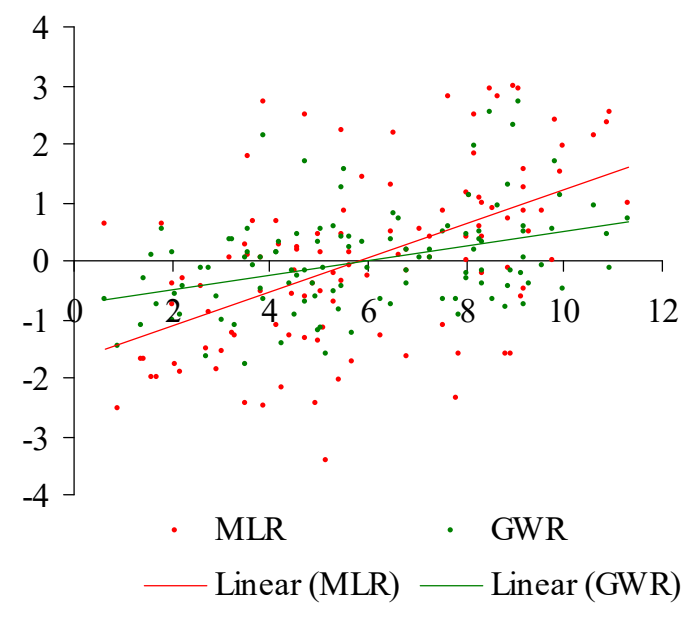

b.

Figure 2. Observed broadleaves CAIv versus MLR and GWR predicted values of (a.), MLR and GWR residuals versus observed CAIv values for broadleaves (b.)

Slika 2. Opservirani $I_{t}^{v}$ lišćara prema MLR i GWR procjenama (a.), MLR i GWR reziduali prema opserviranom $I_{t}^{v}$ lišćara (b.)

Then, we found that observed CAIv values are correlated with MLR and GWR estimates taking into account the magnitude of spatial autocorrelation in all cases. Here are presented spatial correlograms of observed, MLR and GWR estimated CAIv values for conifers and broadleaves. It is visible that MLR and GWR estimates follow shape of variability related to distance of observed values for conifers (Figure 3 a.). Also, residuals are consistent with slightly lower values for GWR (Figure 3 b.). 
Evaluation of MLR and GWR regression models of current annual increment predicted by growing stock, topographical and Landsat 8 spectral data in the northeast Bosnian mixed forest

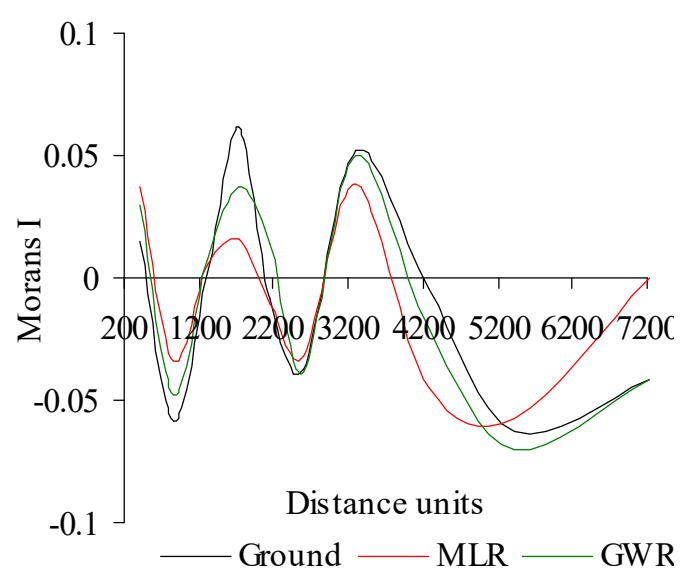

a.

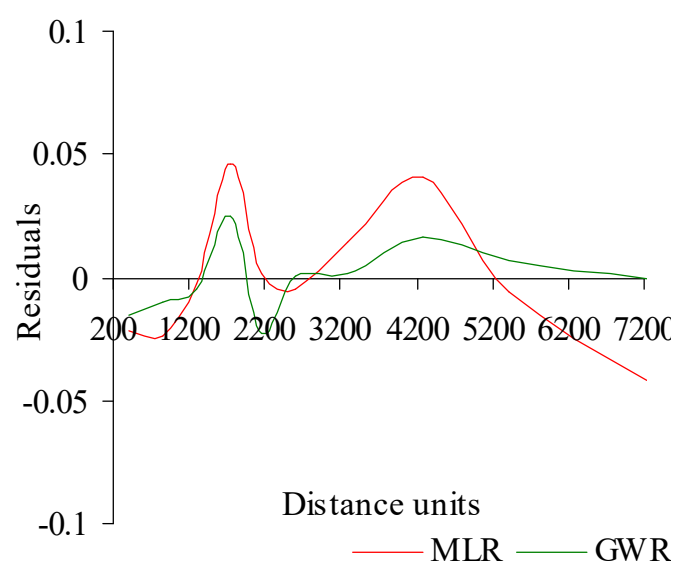

b.

Figure 3. Moran's I for observed, MLR and GWR predicted CAIv values of conifers (a.), MLR and GWR Moran's I residuals versus observed CAIv values for conifers (b.)

Slika 3. Moran I vrijednosti za opservirane, MLR I GWR procjene $I_{t}^{v}$ četinara (a.), MLR $i$

GWR Moran I reziduali prema opserviranim $I_{t}^{v}$ vrijednostima za četinare (b.)

Moran's I of GWR is more consistent with observed variability while MLR shape deviates more for broadleaves (Figure 4 a.). Also GWRv residuals show lower variability for almost all distances while OLS residuals express positive autocorrelation at short distances and negative on long distances (Figure $4 \mathrm{~b}$.). 


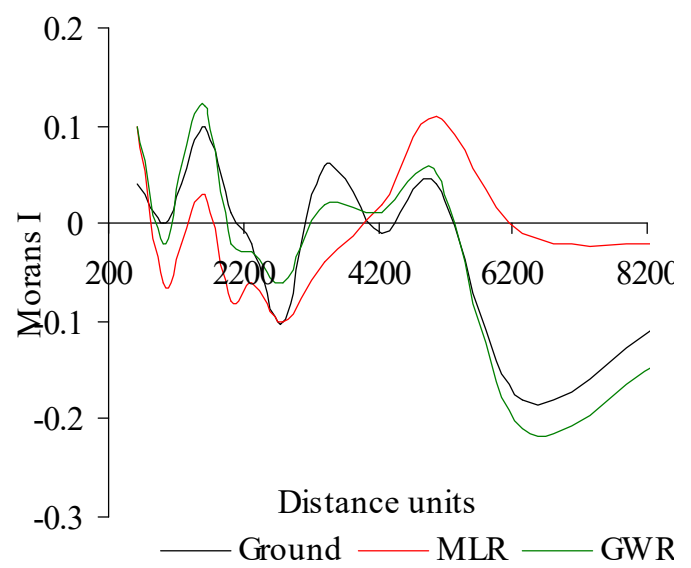

a.

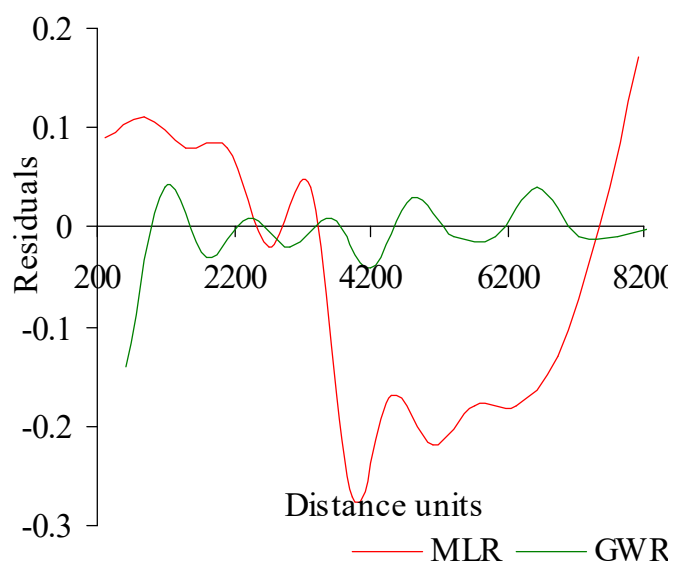

b.

Figure 4. Moran's I for observed, MLR and GWR predicted CAIv values of broadleaves (a.), MLR and GWR Moran's I residuals versus observed CAIv values for broadleaves (b.)

Slika 4. Moran I vrijednosti za opservirane, MLR I GWR procjene $I_{t}^{v}$ lišćara (a.), MLR $i$

GWR Moran I reziduali prema opserviranim $I_{t}^{v}$ vrijednostima za lišćare (b.)

Slight differences in Moran's I and residuals between observed, MLR and GWR estimates variability point out lack of spatial effect on CAIv for conifers. Obtained significant improvement of GWR method for broadleaf's CAIv is confirmed with visible lower Moran's I residuals along all distances.

\section{DISCUSSION - Diskusija}

It is known that spatial terrain and other environmental information related to forest stands contribute to better understanding of forest dynamics (RAis, 2014; LEMPEREUR, 2015; CHARU, 2017; ČERMÁK, 2017). Recently relation between forest structural and other stand variables has been examined including their spatial variation. Here are applied MLR and GWR methods to examine importance and character of structural and environmental variables on CAIv in mixed beech and fir forest on hilly and mountainous positions.

The findings on hilly position provide evidence that growing stock and spectral predictors affects CAIv highly while environmental variation have less influence. This is confirmed by GWR models while all predictors act globally without captured local variation. Similar relation among GWR and MLR is registered by MARTíN-QUELLER (2011) where significant predictors of species richness of woody plants were basal area, annual precipitation, topographic complexity with significant influence of management factors, especially cuttings practice. 
Evaluation of MLR and GWR regression models of current annual increment predicted by growing stock, topographical and Landsat 8 spectral data in the northeast Bosnian mixed forest

Then, it was anticipated that all predictors would have significant influence on CAIv on mountains position but topographic variation do not contribute in regression models. Similarly, the stronger influence of structural predictors, and weaker expression of site and topographic characteristics, environmental and climatic predictors on the current spruce basal area increment was registered by CiENCIALA (2016).

GWR improvements are statistically significant for broadleaves, beech and altogether on mountains position. The results showed that the effects of growing stock and green biomass were not constant over the study area. Local character of particular predictors is obtained for all dependent variables but they differ between conifers and broadleaves. The highest local influences are obtained for broadleaves where their CAIv is affected by growing stock locally. Local impact on conifers CAIv is related to green biomass. The growing stock and green biomass vary from one location to another depending on local conditions influenced by management and environmental factors Non-significance of environmental factor influence in these natural conditions point out importance of management factors emphasizing their role in local situations. These findings are based on GWR showing distinctive performance related to MLR, Also, other research found that GWR provided statistically significant estimates and was important tool for modeling, detecting, and mapping the spatial variability in stand attributes and variables that cannot be revealed by ordinary regression models. (Shriesta, 2006; Propastin, 2008; Tiryana, 2010; Benítez, 2016, Čnítez, 2016, ČABARAVDIĆ ET ALL., 2016). TiRYANA (2010) registered that comparing with MLR, GWR produced better prediction accuracy, revealed local spatial variations in the relationship between structural predictors, reduced AIC, increased adjusted coefficient of determination up and reduced RMSE, what is in accordance with our results. Beside achieved improvements GWR confirmed that structural predictors have stronger influence on CAIv then environmental emphasizing importance of management factors.

\section{CONCLUSIONS - Zaključci}

This research attempted to evaluate two regression methods aiming to identify if structural and environmental predictors had global or local influence on the CAIv on two altitude belts in order to adjust forest management treatments. The management treatments on hilly positions should be performed on standard way focusing on optimal wood production. Findings obtained on mountains positions suggest that management should focus on treatments for high growing stock of broadleaves locally aiming to provide optimal horizontal and vertical structure of tree group in similar local conditions. Clearly, non-significant influence of topographic conditions here pointed out importance of proper planned silvicultural treatments and need for emphasized attention in local situation.

In further research, other forest structural and environmental variables could be considered. More detailed analysis of trees number (per ha), basal area (per ha), 
canopy and other variables impact on the CAIv would identify targets for better planning decisions. Also climate parameters could be included for better quantification of partial variability components of the CAIv. Environmental impact has always been considered in forest management planning but influences were considered as global. More information about separate and interactive global and local influences identify using GWR could contribute to further differentiations of planned silvicultural treatments.

\section{REFERENCES - Literatura}

Austin, M. (2007): Species distribution models and ecological theory: A critical assessment and some possible new approaches. Review. Ecological modeling. 119.

Benitez, F. L., ANDERson, L. O. ANd formaggio A. R. (2016): Evaluation of geostatistical techniques to estimate the spatial distribution of aboveground biomass in the Amazon rainforest using high-resolution remote sensing data. Acta Amazonica. Vol. 46(2): 151- 160.

ChARLTON, M., FotheringhAND, S. AND BRUNSDON C. (2006): Geographically weighted regression. Esrc National Centre For Research Methods. Ncrm Methods Review Papers Ncrm/006.

Cienciala E., Russ R., Santruckova H., StÅHL G. (2016): Discerning environmental factors affecting current tree growth in Central Europe. Science of The Total Environment 573: 541-554.

Čabaravdić A., Osmanović M., Mahmutović G., Mulić S. (2016): Geostatistical Technique for Growing Stock Estimates on Small Forest Stands Using Inventory, Environmental and Landsat 8 Data. Works of the Faculty of Forestry University Sarajevo, 46(1), 1-13.

ČERmÁK P., RYbničEK M., Žid T., AndREAssen K., BørJA I., KolÁŘ T. (2017). Impact of climate change on growth dynamics of Norway spruce in south-eastern Norway. Silva Fennica. Vol. 51(2): 16.

Lempereur M., Martin-StPaul K. N., Damesin C., Joffre R., Ourcival J. M. (2015): Growth duration is a better predictor of stem increment than carbon supply in a Mediterranean oak forest: implications for assessing forest productivity under climate change. New Phytologist. Vol. 207(3): 579-590.

Martín-Queller E., Gil-Tena A. and Saura S. (2011): Species richness of woody plants in the landscapes of Central Spain: the role of management disturbances, environment and non-stationarity. Journal of Vegetation Science 22: 238-250.

NAKAYA, T. (2014): GWR4 User Manual: Windows Application for Geographically Weighted Regression Modelling. GWR4 Development Team.

PROPAStin, P., Kappas, M. AND ERASmi, S. (2008): Application of Geographically Weighted Regression to Investigate the Impact of Scale on Prediction Uncertainty by Modelling Relationship between Vegetation and Climate. International Journal of Spatial Data Infrastractures Research, Vol. 3, pp. 73 - 94. 
Evaluation of MLR and GWR regression models of current annual increment predicted by growing stock, topographical and Landsat 8 spectral data in the northeast Bosnian mixed forest

Rais A., Van de Kuilen J.W., Pretzsch H. (2014). Growth reaction patterns of tree height, diameter, and volume of Douglas-fir (Pseudotsuga menziesii [Mirb.] Franco) under acute drought stress in Southern Germany. Eur J 133(6): 10431056.

RANGEL, T.F.; Diniz-Filho, J.A.F. AND Bini, L.M. (2010): SAM: A comprehensive application for Spatial Analysis in Macroecology. Ecography, 33: 1-5.

SHRiESTA, P. M. (2006). Comparison of Ordinary Least Square Regression, Spatial Autoregression, and Geographically Weighted Regression for Modeling Forest Structural Attributes Using a Geographical Information System (GIS)/ Remote Sensing (RS) Approach. Master thesis. Department of Geography Calgary, Alberta. University of Calgary.

Tiryana, T., TAtsuhara, S. AND Shiraishi, N. (2010): Modeling Spatial Variation in Stand Volume of Acacia mangium Plantations Using Geographically Weighted Regression. FORMATH, Vol. 9, pp. 103 - 122. 


\section{SAŽETAK}

Zapreminski prirast sastojine (po ha) zavisi od strukture sastojine, odnosno taksacionih elemenata koji je karakterišu, ali i od topografskih karakteristika, količine sunčevog zračenja i ostalnih okolišnih varijabli. Višestruka linearna regresija (MLR) integrira značajne prediktore ali daje globalne tendencije promjena zavisne varijable. Poznato je da se u šumskim sastojinama javlja komponenta prostornog varijabiliteta značajnih prediktora, stoga su u ovom istraživanju određeni regresioni modeli pomoću geografski ponderisane regresije (GWR) i idenifikovani prediktori čiji je uticaj lokalni. Materijal istraživanja je sačinjavao uzorak procjena zapreminskog prirasta i drvne zapremine izračunatih za skup od 270 premjernih površina na području gazdinske klase mješovitih šuma bukve i jele na dubokim tlima u sjeveroistočnoj Bosni. Na georeferenciranim tačkama ekstrahovane su vrijednosti nadmorske visine, nagiba i ekspozicije, te 2 PCA komponente dobijene redukcijom digitalnih brojeva seta kanala Landsat 8 satelitskog snimka za dva odvojena dijela površine jedinstvene gazdinske klase: na nižem brdskom dijelu i višem planinskom dijelu. Za određivanje regresionih veza zapreminskog prirasta sastojine i navedenih prediktora primjenjeni su MLR i GWR. Regresionom analizom je ustanovljeno da su uticaji značajnih prediktora na brdskim predjelima globalni, dok su se na planinskim predjelima ispoljili lokalni karakteri uticaja drvne zapremine lišćara i prve PCA komponente koja se odnosi na zelenu biomasu. Geografski ponderisanom regresijom je ostvareno statistički visoko signifikantno poboljšanje procjene tekućeg zapreminskog prirasta lišćara od drvne zapremine $(\mathrm{p}<0.001)$, povećanje procenta objašnjenja varijabiliteta za oko $11 \%$ i redukcija relativne greške procjene od oko $6 \%$, dok ispoljeni lokalni uticaj prve glavne komponente (zelene biomase) na tekući zapreminski prirast četinara nije značajno poboljšao procjenu. Ovo istraživanje ukazuje na mogućnost povećanja zapreminskog prirasta sastojina prilagođavanjem uzgojno-tehničkih mjera lokalnim prilikama a koje bi omogućile skupinama lišćarskih vrsta drveća da u većoj mjeri koriste proizvodni potencijal staništa i ostvare veće priraste zapremine. S obzirom da zapreminski prirast sastojine zavisi i od ostalih taksacionih elemenata sastojine, potrebno je analizirati i njihov uticaj, provjeriti karakter njihovog djelovanja te modelirati prostorne odnose što većeg broja prediktora radi unapređenja planiranja uzgojno-tehničkih mjera.

Corresponding author: Azra Čabaravdić; Faculty of Forestry University Sarajevo; Zagrebačka 20, 71000 Sarajevo, Bosna\&Herzegovina; e-mail: a.cabaravdic@sfsa.unsa.ba 